\title{
Kihnu pärimustantsud minevikus ja tänapäeval
}

Ingrid Rüütel

Teesid: Kihnu saarel on tänaseni säilinud märkimisväärne hulk pärimustantse, mis on käibel nii traditsioonilises kui ka uues kontekstis. Pärimustantse tantsitakse traditsioonilistes perekonna- ja kalendrikommetes (kosjades, noorikumajas, pulmades, kadripäeval), seltskonnatantsudena mitmesugustel pidudel ja muudel kogunemistel ning organiseeritud esinemistel (turistidele Kihnus, festivalidel jm üritustel kodusaarel ja väljaspool, sh välismaal). Esinejaks on peamiselt folkloorirühm Kihnumua, kes tegutseb üle 30 aasta Katrin Kumpani juhtimisel. Rühma koosseis on muutuv, kuna pärimuskultuuri tundmine on saarel üldine. Tantse on õpetatud ka koolis, rahvamajas ja tantsuklubis.

Kadunud on rituaalne voortants pulmaratas, samuti paaristants labajalg. Populaarsed on kõlmõpuari, neljäpuari ja rida paaristantse, mida tantsitakse ringis: Kihnumua, sõrmõlugu, Tõmba Jurka, varõs, aissa, vindirka (vengerka), valss, reinlender, Kihnu polka jm. Paljudel laiemalt tuntud tantsudel on saarel oma variandid ja oma stiil. Tantsivad kas segapaarid või naised omavahel peamiselt akordioni saatel. Ka pilli mängivad tihti naised. Torupilli enam ei mäletatagi, viiuldajaid oli veel läinud sajandi teisel poolel, viimastel aastatel on haruldaseks jäänud ka lõõtspill.

Märksõnad: folkloorirühm Kihnumua, Kihnu, paaristants, pulmaratas, pärimustants, rituaalne tants, seltskonnatants, voortants

Kihnu säilis pikema ajalooperioodi jooksul suhteliselt suletud kogukonnana. Traditsiooniline elukorraldus ja kogukondlik eluviis püsisid läinud sajandini. Mehed püüdsid kala või teenisid laevadel. Nad tagasid perele põhilise sissetuleku ja tõid teistelt maadelt kaasa ka uuendusi. Naised korraldasid koduseid asju, tegid põllutööd ja hoidsid vaimseid väärtusi. Ka nõukogude ajal kalurikolhoosi päevil käisid mehed merel ja olid põhilised rahateenijad, naised töötasid kodusaarel, askeldasid kodus ja hoidsid traditsioone nii kodus kui ka kogukonnas.

Alalhoidlikust elulaadist tingituna on saarel kõrvuti elanud erinevad kultuurikihistused alates eelkristlikest traditsioonidest (pulmakombestik, regi- 
värsiline rahvalaul ja vanad ringtantsud) kristlike, peamiselt ortodokssete tavade ja lauludeni; 19. sajandi lõppriimilisest rahvalaulust ja paaristantsudest kuni tänapäeva rahvalike laulude, seltskonnatantsude ja massikultuurini.

\section{Tants kui kultuuriline protsess (teoreetiline alus ja uurimismeetodid)}

Kihnu saarel on seega tänaseni säilinud märkimisväärne hulk vanemaid ja uuemaid tantse, mis on käibel nii traditsioonilises kui ka uues kontekstis.

Vanimaks koreograafiliseks vormiks on liikumine suletud ringis regivärsiliste laulude saatel. Analoogseid liikumisi laulude (ballaadide) saatel nimetavad näiteks fäärlased tantsudeks. Kihnus nimetatakse sellist liikumisvormi rattaks nagu pilli saatel tantsitavat pulma voortantsugi, kuid ei peeta tantsuks. Küll aga peetakse tantsuks uuemate ringmängude vahetantsudena kasutatavaid seltskonnatantse (reinlendrit, valssi jm), mida samuti saadab üksnes laul.

Tegelikult sisaldab koreograafia elemente ka pulmalaulude tavaline esitusviis - rühmas (varem enamasti poolkaares) üksteisest kinni hoides paigal tammudes ja kahele poole õotsutades. Euroopa kultuuriruumis paigal liikumist tavaliselt tantsuks ei peeta, ka kihnlased ei pea seda tantsuks, kuid mõnedel põhjarahvastel (nt eskimotel) peetakse tantsuks ka rütmilisi liigutusi seistes või istudes.

Tantsu definitsioone on erinevaid. Ühe kaasaegse tantsu definitsiooni kohaselt tants on keha liikumise esteetiline koordinatsioon (Marrazzo 1975, tsiteeritud Delgado 2005). Kuid see, mis on esteetiline, on ise problemaatiline ja mingis ühiskonnas esteetiliseks peetavad tantsud ei tarvitse seda sugugi olla võõra vaataja silmis. Ka sama sootsiumi sees võivad arusaamad esteetilisest erineda. Lisaks on tantse, mille puhul ei ole esteetiline kriteerium tantsijatele oluline, näiteks mõned meeste erootilised tantsud, parodeerivad tantsud jms. Sotsiaalantropoloogilise määratluse järgi on tants keha sotsiaalne ja kultuuriline konstruktsioon liikumises (Delgado 2005: 65). See definitsioon haarab mitte üksnes "keha" ja "liikumise", vaid ka tantsu sotsiaalsed ja kultuurilised aspektid.

Üks tuntuimaid jaotusaluseid liigitab tantsud rituaalseteks ja lõbustuslikeks (seltskonnatantsudeks). Kultuurianalüütilise tantsu-uurimise tüpoloogias eristatakse tantsude viit funktsiooni:

1. tants kui sotsiaalse organisatsiooni kajastaja,

2. tants kui mingi rituaali väljendaja, 
3. tants kui lõbustus,

4. tants kui psühholoogiline "tagavaraventiil",

5. tants kui esteetiline tegevus ja esteetiliste väärtuste kajastaja (Hoppu 1999: 18-19).

Sotsiaalantropoloogilise arusaama kohaselt saab tantse mõista vaid üldisemal kultuuritaustal, kuna nad kajastavad ühiskonna struktuuri, ajalugu, norme, väärtusi ja uskumusi. Tänapäeva kultuuriuurimustes pööratakse aga erilist tähelepanu asjaolule, et kõik need fenomenid on pidevas muutumises nagu tantsud isegi: tants ise on protsess, milles avaldub kultuur (Saarikoski 2003: 11-12). Viimaste aastakümnete tantsu-uurimine lähtubki suuresti kultuurist ja on suunatud kontekstile: uuritakse tantsu situatsioone, tantsimise kohti, tantsijaid, pillimehi, nende poolt tantsule ja tantsimisele antavaid tähendusi. Kuigi tants on mitteverbaalne, saab tantsust rääkida.

Järgnevalt antakse ülevaade Kihnu tantsude ajaloost, tavadest, seostest rituaalidega, tantsimise situatsioonidest ja paikadest, soorollidest ning Kihnu pärimustantsude tänapäeva olukorrast. Tantsude struktuurianalüüs jääb käesoleva artikli raamidest välja. Kasutatud on kõiki varasemaid kirjalikke teateid, kuid oluliseks meetodiks on olnud ka isiklikud folkloristlikud välitööd, intervjuud, videosalvestused ja osalusvaatlus. Olen ise jäädvustanud Kihnu tantse ja muud folkloori alates ülikooli rahvaluule suvepraktikast 1956. aastal kuni 2008. aasta suvel toimunud pulmadeni, osalenud paljudes pidustustes ja enamikku tantse ka ise tantsinud. Samuti tunnen paljusid Kihnu inimesi, kellelt lisaks vahetule suhtlemisele, audio- ja videointervjuudele olen saanud täpsustavaid teateid ja tagasisidet ka kirja ja meili teel. Siin kohal tahaksingi tänada kõiki Kihnu inimesi, eriti aga Rosalie Karjamit, Mare Mätast, Maie Aava ja Veera Least väärtuslike märkuste ja lisateabe eest.

\section{Kihnu tantsud ja tantsumuusika}

Vanimaks pilli saatel esitatavaks tantsuks oli pulmades tantsitav voortants (ratas), mis on aga käibelt kadunud. 1950. aastatel seda rituaalset tantsu veel tantsiti, kuid tähendust ei mäletatud. Ainsaks tantsuks, mille maagilisest funktsioonist teatakse rääkida tänapäevalgi, on naiste sigivusmaagiline tantsimine vana katoliku kabeli müüridel. Tantsust endast midagi lähemalt ei teata (ERA, DV1, $1 ; 16){ }^{1}$

Vanim lõbustusliku funktsiooniga tants - labajalg hakkas taanduma juba 1930. aastatel (ERA II 133, 613/4 (137) - T. Saar 1937). 1850. aastal sündinud Liis Alasi lapsepõlves olevat tantsitud aga veel ainult labajalga (ERA II 56, 206 
(26) - H. Tampere 1933). Tantsu on nimetatud ka mualugu, vanadenaiste tants ja putierus (ERA II 128, 39/40 (6) H. Tampere < T. Saar 1936). Putierus (putierusõ usk) ehk lutierus tähendas kihnu keeles luteriusku. See tähendab, et tants on ajast enne saarerahva veneusku minekut, s.t enne 19. sajandi keskpaika (ERA II 128, 41 (10) H. Tampere < T. Saar 1936). Millal see käibele tuli, pole teada. 1930. aastatel tantsiti ka ratast, aga samuti eelmistega võrreldes uuemaid tantse, nagu kalamiest, sõrmõlugu, varõst (nimetatud ka paljaspiä ja kargamiselugu), kolmõpuari (ka raskatsai ja mõrsipulka), Kihnu valssi ja polkat, pulgatantsu, paabiljonipolkat ehk takkalaadit.

20. sajandil on kihnlaste tantsuvara olnud väga rikkalik. 1950. aastate keskel tantsiti pulmades kalameest, sõrmelugu, krakovjakki, padespaani, voorimeest, tinnat, kikamuri, oirahhi, katariinat, takkalaadit, jooksupolkat, perekonnavalssi, tuljakut (viimast nimetati terve vald), 1-2-3-4-5-6-7-t, polka ja valsi kohalikku erikuju (RKM II 56, 325/7 - O. Niinemägi (Kõiva) 1956; TRÜ EKRK I9, 403 - 488 - M Sakkis (Sikk), I. Ruus (Rüütel) 1956). Rahvamajas tantsiti samal ajal või demonstreeriti kogujatele ka selliseid tantse nagu kolmepaari, neljapaari, kahtepaari, subota, kihnumaa (paadis kiikriga), Katariina Lempsis, tõmba Jürka, aissa, mitut vingirka varianti, (k)uhaanuška, Viru uulitsal, vares, itata, tangoo ja valtsemuur. ${ }^{2}$

Tänapäeval populaarsed seltskonnatantsud on (nüüdisaegses Kihnu kõnepruugis) kolmõpuari, neljäpuari ja rida ringis tantsitavaid paaristantse: kalamies, kihnumua, sõrmõlugu, 1-2-3-4-5-6-7, tõmba Jurka, reilender, vindirka ('vengerka'), krakovjak, aissa, padespaan, kihnu valss, kihnu polka. Nagu 1950. aastatel nii ka nüüd tantsivad sagedamini naised omavahel, harvem ka segapaarid. Tantsida oskavad ka lapsed ja pidudel tantsivad nad koos täiskasvanutega. Nimetatud tantsud on püsinud tänaseni pidudel seltskonnatantsuna käibel suurelt osalt tänu sellele, et need on võtnud oma repertuaari nüüd juba üle 40 aasta tegutsenud folklooriansambel Kihnumua. Koolis on õpetaja Anne Buravkova õpetanud mõningaid tänapäeval Eestis mujalgi lastele õpetatavaid tantse, nagu Kaks sammu sissepoole, Kükita, kuid need pole seltskonnatantsudena laiemalt käibele läinud. Küll tantsitakse vahel seltskonnatantsudena 1970.80. aastatel Kihnu koolis õpetatud jooksupolkat ja kaerajaani. Jooksupolkat on juba varemgi õpetatud.

Kui 1950. aastatel mängiti tantsuks peamiselt lõõtsa, siis nüüd on põhiline saatepill akordion. Rea tantsude juurde kuulub ka laul, mida on laulavad või on laulnud tantsijad ja/või pillimehed pillile kaasa. Osa laule on lühikesed ja neid ei lauldud kogu loo kestel (kihnumua, sõrmõlugu, oirah, 1-2-3-4-5-6-7, voorimees jmt ), osa on pikad, mida võidi laulda kogu tantsuloo kestel (näiteks valsid, reinlendrid jm). Õieti on need laulud, mille meloodiad sobivad tantsuks (valsiviisil lauldav "Maretsa jõe kaldal” jmt). Varem oli tantsulaule rohkem. 
Labajalgade juurde laulsid pillimehed humoristlikke, vahel ka rõvedasisulisi värsse, mille meloodia põhines mingi labajalaloo ühel osal, koosnedes tavaliselt $4-8$ taktist.

Oh sina tulinõ kurat!

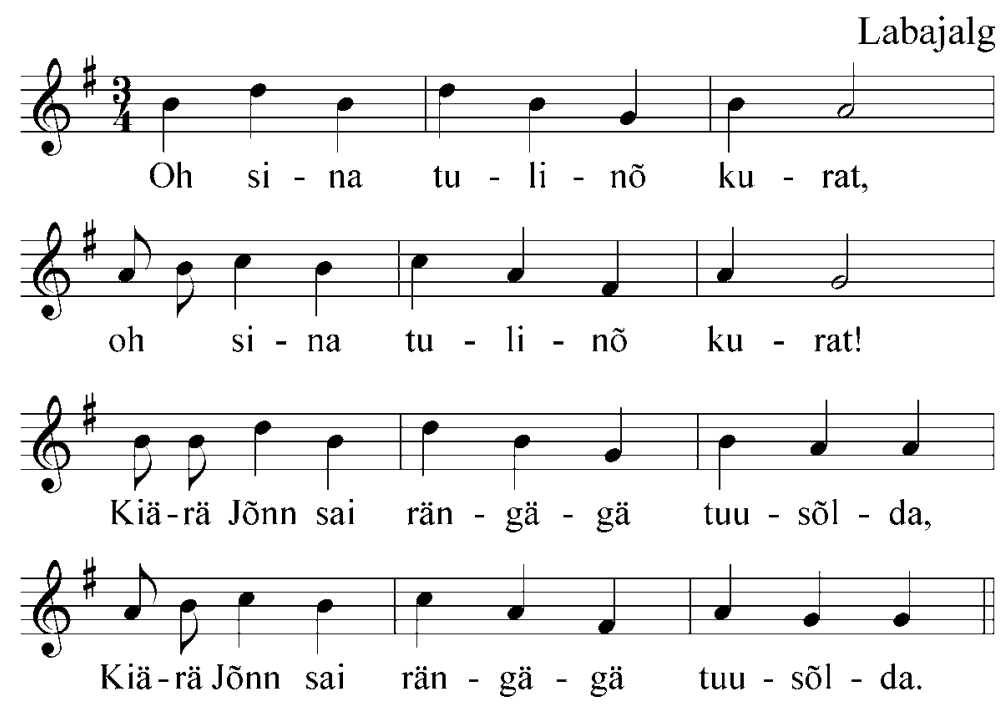

Nii laulnud Laosõ Mihkel Kihnu kõrtsi ees ja tantsinud ise.

Kiärä Jõnn saanud kakluses peksa. Rängägä = väga palju.

Lühikesi salmikesi laulsid pillimehed varem ka polkalugudele jt tantsudele kaasa. Laulude saatel tehti ka ringmänge, mille salmide vahele lükitud laulukeste saatel tantsiti peamiselt polkat, valssi või reinlendrit.

Pillidest torupilli enam ei mäletatagi, viiuldajaid oli veel 20 . sajandi teisel poolel. 19. sajandi kuulsaim viiuldaja oli vana Marus Linakülast, kel olnud viiul kõikjal kaasas, isegi hülgepüügil. Üks tema kuulsaid lugusid oli "Lõolugu”, mis kujutas lõokese lauluga lendutõusmist ja hiljem kuulus teistegi viiuldajate repertuaari. 20. sajandi parimateks viiuldajateks peeti Matu Juri (Juri Laasenit) Rootsikülast ja Juhani Juri (Juri Vidrikut) Lemsi külast. Mängida oskasid oli aga paljud. Viimased tuntuimad viiuldajad oli Theodor Saar ja Mihkel Mäes.

Pulmades on vanasti tantsuks mängitud ka konnapilli (parmupilli). Tantsijad pidanud takti pillimehe jalalöökide järgi, kes ahju ees istunud ja jalaga vastu maad takti trampinud (RKM II 43, 194 - T. Saar 1955). Konnapillile 
löödud vahel kaasa trummi ja trianglit. Kõiki neid valmistati kohapeal. Trumm tehti tavaliselt koeranahast. Trummi, tamburiini ja trianglit mängiti ka lõõtspilli saateks.

Varem oli küla “orkestri” koosseis järgmine: peapill lõõts, /lisaks / viiul, trumm, triangel. Viiuldaja istus lõotsamehe paremal pool, et paremini viisi kuulda ja mängis sama viisi mis lõõtski. Osavamad viiuldajad mängisid viisi vahest ka oktaav madalamalt või kõrgemalt kui lõots, mõni isegi kombineeris natuke saadet. Trumm ja triangel istus lõotsast vasakul. Nende pillidega löödi pidevalt takti kaasa. Trummi löödi "rummu nuiaga”. Mõni lõi trummi ka käega: rõhulisel taktiosal põristati pöidlaga mööda trumminahka, rõhututel taktiosadel löödi vastu trummi sõrmenukkidega. Nuiaga trummi lü̈̈es löödi vahelduseks rõhulisel taktiosal käepäkaga vastu trummi vitsa, rõhutul taktiosal nuiaga vastu trummi nahka. Vahest mängis kogo ka paar lõotsa ja viiulit. Nü̈̈d on pillideks tantsu saateks harilikult bajaan või akordion. Vahest on neid pille ka kaks korraga mängitud, samuti ka viiul (RKM II 43, 192 - T. Saar 1955).

Hiljem ei ole viiulit, trummi ja trianglit bajaani ja akordioni kõrvale mängitud.

Viimastel aastatel on haruldaseks jäänud ka 19. sajandi teisel poolel kasutusele tulnud lõõtspill, mis oli saarel aastakümneid "peapilliks". Läinud sajandi keskel oli kuulsaim lõõtsamees Loego Jua ${ }^{\mathrm{e}}$ (Jaan Alas), kes mängis ka Tartu Ülikooli rahvaluule kateedri poolt valmistatud filmis "Kihnu saare pulmakombestik" 1956. aastal. 20. sajandi teisel poolel olid head lõõtsamehed Jaan Türk, Jaan Köster jt. Viimaste aastate pulmades enam lõõtsa kuulda ei olnud. Ainus vana lõõtsamees Jaan Köster enam pulmades mängimas ei käi. Küll mängitakse veel karmoškat: noored õpetajad Ly Leas ja Külli Sepp oskavad seda mängida ning 1997. aasta kadripeol tekkis neil peo käigus spontaanselt tore koosmäng vana pillimehe Jaan Türgiga.

Esimese bajaani tõi saarele 1930. aastate algul pikemat aega USAs elanud Pulli Pärt (RKM II 43, 191 - T. Saar 1955). Akordion on pärit umbes samast ajast. Esimese akordioni omanik saarel oli mandri päritolu vallavalitsuse ametnik. Akordione ja bajaane toodi ka sõja ajal Rootsist. Millal jõudis Kihnu vene karmoška, ei ole teada.

Veel 1950. aastatel oli pillimäng meeste pärisosa. Pillimängijad olid ikka ja on ka praegu poisid, mitte ühtki tüdrukut. Ka abielumeeste mängimisest tantsuks ei peeta lugu. Selle kohta öeldakse: "Naesõmehe pill nagu soendõt supp" (RKM II 43, 189/97 (4) T. Saar 1955).

Tänapäeval mängivad tantsude saateks akordioni peamiselt naised - viimastes pulmades mängisid Õie Vesik ja Helga Michelson, kes on pillimängu 


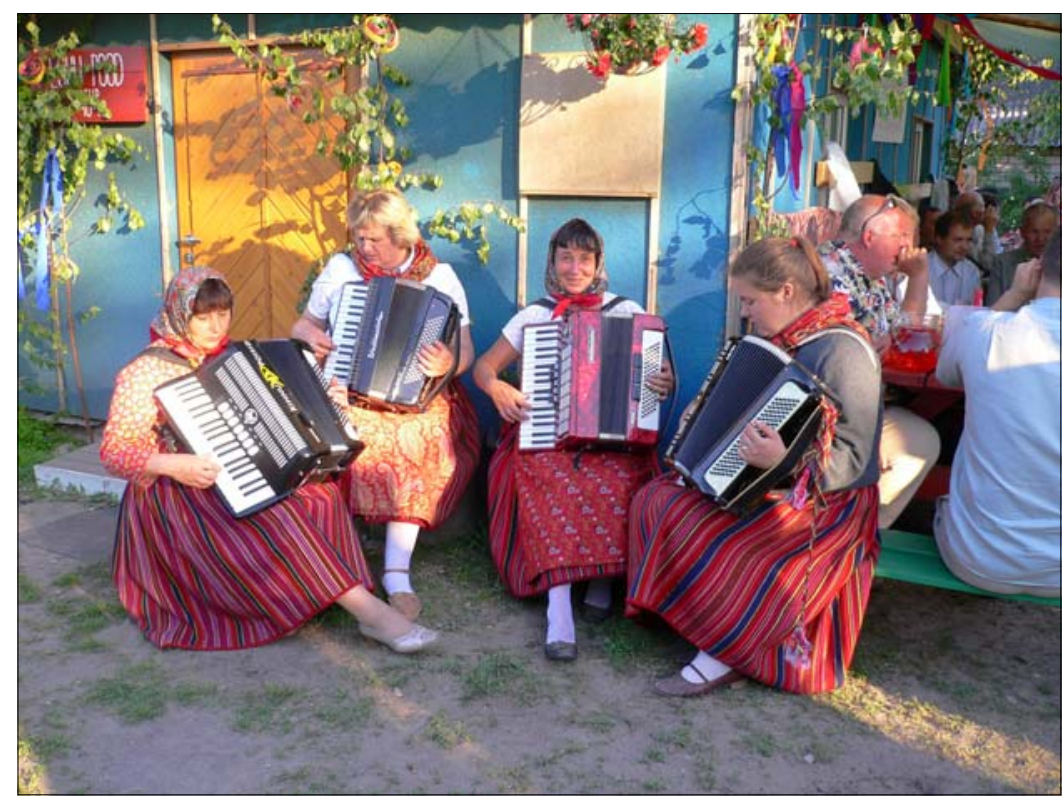

Foto 1. Pulma pillinaised. Ingrid Rü̈̈tli foto 2007.

õppinud oma isalt, tuntud pillimehelt Viktor Vesikult, koolidirektor Lea Jõgisuu, noor akordionimängija on Reet Laos. Akordioni mängivad ka kooliõpetajad Ly Leas ja Külli Sepp. Kõik nad on kohalikud. Pulmades ja muudel pidudel mängitakse tihti mitut pilli korraga. Akordioni mängib ka Uuno Karotamm, samuti võivad mõnikord hea pillimänguga tantsijaid üllatada Järsumäe Eedi ja Oru Endel. Pulmades on pilli mänginud ka Sarapuu Silvi oma mehe Margusega (Mare Mätase kiri autorile).

Uued üllatajad on tosin aastat tegutsenud Kihnu Poisid. Ansambli põhituumikusse kuuluvad akordion, kaks kitarri ja trumm, vahel lisatakse muid pille. Oluline komponent on laul. Põhirepertuaari moodustavad vanad Kihnu meestelaulud. Paraku mängivad Kihnu Poisid nüüd juba rahateenimise eesmärgil rohkem mandril kui kodusaarel. Ent tänu Kihnu Poistele on Kihnu tantsustiil kandunud ka linnaruumi: Pärnu Kuursaalis peetakse tantsuõhtuid, kuhu koguneb palju kihnlasi nii linnast kui kodusaarelt, ning muude tantsijate ümber moodustatakse oma Kihnu ring.*

Viimasel ajal on pulmades ja muudelgi pidudel tantsuks mänginud kohalikest meestest koosnev Kihnu Kamp, kuhu kuulub kaks kitarristi (üks neist ka laulab) ja trummimees. Mängitakse vanemaid mandrilt pärit lugusid, ka Kihnus tuntud laule, mille saatel tantsitakse ringis Kihnu polkat, valssi või reinlendrit. Juba 1980. aastatel, võib-olla varemgi on Kihnu tantsuks mängima kutsutud mandri punte ja pillimehi. Mitmed tuntud ansamblid, nagu Kuker- 
pillid, Väikeste Lõõtspillide Ühing ja Untsakad on ise leidnud tee Kihnu saarele, siin lugusid õppinud ning mõnegi moest läinud loo taas nii saarel kui ka mandril populaarseks mänginud ja laulnud. Viimastel aastatel on pidudel sagedased Pärnu Poisid ja Audru Jõelaevanduse Punt, kes mängivad ka mõningaid Kihnu tantse.

\section{Naiste ja meeste rollist tantsukultuuris}

Kui tänapäeval on tants peamiselt naiste ja neidude lõbu, siis vanematel aegadel oli siin meestel ilmselt küllalt tähtis roll. Nimelt olid just mehed paljude tantsude Kihnu toojad. Kuulsa Kihnu pulmalauliku Liis Alasi andmetel olevat polka Kihnu toonud Uieda Jõnn 1870. aastatel Taanimaalt. Reet Sutt Linakülast on aga väitnud, et meremõõdud käinud Kihnus ja õpetanud polkatantsu (ERA II 172, 111 (1) - H. Tampere 1937). Aga ka nimetus Kalamies võib osutada tantsu loojatele või maaletoojatele.

1935. aastal sündinud Roosi Karjami lapsepõlves on tantsitud marsipolkat ja kiigadi-kaagadit, mõlemal olid ka laulusõnad. Viimast õpetanud laevalt koju tulnud Muru Jüri, Suti Jass (Jakob Sutt) aga toonud saarele sarlestoni (Jüri Niine) (Roosi Karjami kiri autorile). Koos oma õega harjutanud nad viimase kodus selgeks ja õpetanud siis teistele. Tšarlston nõudis aga eriti kergeid jalgu, oli kihnu tantsudest väga erinev ja suurt populaarsust ei saavutanud, lühiajalise levikuga olid ka eespool mainitud marsipolka ja kiigadi-kaagadi. Varem on mõnel määral tantsitud ka fokstrotti.

Arvestades asjaolu, et enamikul tantsudest on olemas Euroopas paralleelid, võib oletada, et merd sõitnud ja paljudes kõrtsides peatunud mehed olid üldse Kihnu uuemate tantsude tekke juures suured osalised. Võõrsil tantsimisest on juttu ka kihnu meremeeste lauludes:

:,:Nü̈̈d mina palun vaigist ilma, et saaks Liverpoli minna.:,:

- - -

:,:Õllepoed ja trahtrid lahti

kokk jääb üksi laevavahti.:,:

:,:Seal oli palju lõbu jahti

preilidega tants läks lahti.:,:

,:Kas olgu poiss või naisemees

meil kõigil rõõmus süda sees.:,:

(http://www.kihnupoisid.pri.ee/?inc=32\&laul_id=557\&) 
Paljud uuemad, pärast I maailmasõda populaarseks saanud peotantsud levisid Kihnus nagu mujalgi Eestis Tallinnas korraldatud tantsukursuste kaudu. Kihnlastest osalseid neil näiteks Jüri Vahkel, Nikolai Pull jt. Nii levisid Kihnus sellised tantsud nagu aissa, varõs, uhaanuška, suboota jm. See on teema, mis vääriks edaspidi konkreetsemat uurimist. Eesti Rahva Muuseumi pidudelt toonud aga seal osalenud Kihnu rühm kaasa pulgatantsu, mis saarel mõnevõrra levis, kuid on nüüd unustatud.

Kuid ka naised käisid mandril teenimas ja võisid sealt tantse kaasa tuua. Nii on Marina Rooslaidilt üles kirjutatud saarel vähe tuntud tantsud, nagu itata ja valtsemuur, mida ta on ka teistele õpetanud. Ta demonstreeris meile ka tinnat (täiesti erinev 1950. aastatel Tartu tudengite seas levinud tantsust). See olevat meeste naljatants, mida ta näinud tantsimas sõjavange. Sama tantsu on kirja pannud aga ka Theodor Saar, kes olevat seda näinud mitmelt isikult (pole märgitud, kas meestelt või naistelt) ning arvab, et see on toodud Ruhnust pärast rootslaste väljarändamist 1944. aastal (RKM II 43, 139/1 (8) 1955).

Mis puutub tantsude ja ringmängude liikumissuunda, siis on uurijate tähelepanu köitnud asjaolu, et sageli liigutakse vastupäeva. Algsem oli päripäeva liikumine. Vastupäeva liikumisel ja ümberdamisel oli vanasti kindel tähendus - seda tehti millegi vastu, s.t millegi halva ärahoidmiseks, näiteks tõrjemaagilise tähendusega venna suitsu ajal (Rüütel 1995). Miks tantsitakse siis tihti muid tantse vastupäeva?

Sellise moe olevat Kihnu sisse toonud I maailmasõjast tagasi tulnud mehed:

Moodsamad poisid sundisid vahest tantsijaid tantsima vastupäeva sellega, et hakkasid päripäeva tantsijaile hooga vastu vastu tantsima (ERA II 133, 613/4 (137) T. Saar 1937).

Sealtpeale olevatki vastupäeva liikumine moodi läinud, kuna päripäeva liikumist peetud vanamoodsaks.

Kas I maailmasõjast tagasi tulnud mehed ka mingeid uusi tantse kaasa tõid, ei ole konkreetselt teada, kuigi seda on arvatud. Vahest oli selleks russki ehk kasatski, mida tantsisid purjus mehed ja millest Kihnus tunti üht eriti räiget varianti (vt ERA II 168, 529/30 (34) T. Saar 1937). Tantsu juurde kuulus ka venekeelne lauluke (samas). Kuid see oli erinevate teisenditena ka mujal Eestis levinud. Katrin Kumpan kirjutab:

Ennemä tansiti russkit, sie oli kua üks kõnkamine vene põlvõtansu muõdi. Entsed tsaari armee soldatid tantsn valgõ taskurätikuga ning tein tohmi. Viimne, kis neid tantsa tantsis, oli Merässe Liisi, kui naestõ jahti pieti aastal 1966 (Kumpan 2008). 
Seega tantsisid seda meeste tantsu erilisel juhul paroodiana ka naised.

Enamik Kihnu tantse on tuntud ka mandri-Pärnumaal, kuid mõnelgi puhul on raske öelda, kas need levisid sealt Kihnu või vastupidi. Igatahes on tantsud Kihnus muutunud omanäoliseks ja omandanud lokaalse stiili. Tantsude koreograafiline analüüs jääb selle artikli piiridest välja.

Paradoksaalne on, et kuigi mehed olid paljude tantsude Kihnu toojad, olid pidudel põhilised tantsijad siiski naised: Kihnus tantsisid endisel ajal ainult naised ja nü̈̈dki on segapaarid kaunis haruldased (ERA II 128, 41 (11) H. Tampere < T. Saar (1936).

Sellel oli nähtavasti mitu põhjust. Mehed olid merel, Kihnu oli suurel määral naiste ühiskond. Kuid konservatiivsetes kihnlastes tekitas segapaaris tantsimine algul ka mõningat võõristust. Liis Alas (sünd 1850) on jutustanud:

Tantsisid ainult tüdrukud ja naised. Mehed vaatasid päält (ka nüüd enamasti nii). Ennem olnud see häbiasi ja naerdav, kui tüdruk poisiga tantsima läks (ERA II 56, 206 (26) H. Tampere 1933).

Aja jooksul muutus segapaaris tantsimine siiski tavaliseks, kuigi ka praegu näeb tantsupõrandal rohkem naisi. Segapaaridega tantsimist on kindlasti soodustanud ansambli Kihnumua, samuti koolilaste rühmade tegutsemine, kus paljud poisid on tantsima õppinud või oma tantsuoskust lihvinud ja tantse juurde oppinud. Segapaaridena tantsivadki sagedamini noored. Vanemad mehed on tagasihoidlikumad. Kadripidudel väiksemas seltskonnas, eriti kui pidu hoogu satub, võtavad ka mehed rohkem tantsudest osa. Rahvamajas ja muudel pidudel näeb segapaaridena tantsijate seas muidugi alati rohkesti turiste, kes tantsivad omavahel, aga ka Kihnu tüdrukutega.

\section{Tantsimine traditsioonilistes perekonna- ja kalendrikommetes}

Keskseim sündmus, mis koondas enda ümber traditsioonilise kultuuri eri žanre ja vorme (kombeid, laule, tantse, traditsioonist käsitööd) ning aitas neil säilida meie päevini, oli pulm. Kihnu pulm on oma põhialuselt kahe suguvõsa lepingut kinnitav nn suguvõsapulm, mis lähtub sugukondlikust ühiskonnakorrast ja tugineb eelkristlikele usukujutelmadele ning on oma põhijoontelt läänemeresoome rahvastele ühine.

Nn kahe poolega ehk kahe otsaga pulm peetakse eraldi nii pruudi kui peigmehe kodus, kusjuures kesksemates rituaalides osalevad mõlemad pooled koos ja need toimuvad vanade regivärsiliste pulmalaulude saatel. Aastal 2007 peeti üle pikema vaheaja taas kahed traditsioonilised kihnu pulmad ja 2008. aastal veel ühed. 
Oluline koht pulmades on veimevakal, mida hakati valmistama juba lapseeas. Käsitööoskus pärandati emalt ja vanaemalt, kuid siin oli oma osa ka käsitööõhtutel (nn ülaljõstmisõd ehk laudaõhtud).

\section{Tüdrukute ülalistumised}

Jakobipäevast kuni kevadise maarjapäevani, välja arvatud paastuajad, kogunevad tüdrukud sagedasti neljapäeva ja pühapäeva ôhtuti kuskile tuppa või tüdrukutelauta (väluhoone, kus tüdrukud suvel magavad). Igal ühel on kaasas midagi väikest tööd, nagu sukavardad, vööde kudumine ja heegeldus, kusjuures ka lauldakse. Kui tulevad sinna poisid pillidega, siis ka tantsitakse. Vanasti ja ka praegu (ERA II 95, 84/5 (16) Peeter Köster, Lemsi k 1935).

Pulmade eel korraldatakse nn nuõrikumaja, kuhu kogunevad mõrsja sõbratarid, et aidata tal veimevakka valmistada. Töötegemist saadab alati laul. Hiljem saabuvad poisid koos pillimehega ja algavad tantsud ning ringmängud.*

Nuorikumaja korraldati Kihnus ka viimaste pulmade eel, kuid neis ei tantsitud, sest polnud pillimängijaid poisse. Ka käisid noorikumajas abiks vanemad naised.

Pulmades tuleb eristada rituaalseid tantse ja tavalisi seltskonnatantse.

Enamasti lauldakse rituaalseid pulmalaule poolkaares seistes ja jalalt jalale tammudes. Ringis (rattas) liikudes lauldakse vaid mõned spetsiaalsed laulud teatud kommete puhul, näiteks kui peiupoolsed jõuavad noorikumaja õuele. Pulmalaulikud on eranditult naised.*

Rattas laulavad ka noorikupoolsed teisel päeval noorpaarile külla tulles pulmamaja õuel. Kasutati erinevaid käteasendeid: üks käsi eesseisja õlal, teine puusal või lahtiselt all, hoiti käe alt kinni jm (Kõiva 1987).

Eriline rituaal on nn venna saun. Pruudi vend kütab enne külaliste saabumist toa soojaks ning suleb kõik avad, nii et suits välja ei pääse. Pruudi sugulased laulavad saabudes suitsuses toas erilist laulu, liikudes vastupäeva suletud ringis. Komme oli seotud kadakasuitsu puhastava toimega (kõik putukad, haigus ja kurjus aeti suitsuga maha).

Rituaalne voortants oli pulmaratas ehk lihtsalt ratas. Varem torupilli, hiljem viiuli saatel liiguti kätest kinni hoides vahetussammudega, käidi läbi erinevad paigad pulmamajas ja selle ümbruses. Esimene vedas, tegi igasuguseid keerutusi, parsil isegi käidud ja aknast välja ja laua alt läbi ja igalt poolt... (T. Saar). Tantsu pole ammu tantsitud, kuid seda mäletatakse.*

Tänaseni elab aga pulmakommetes rituaalne pruudi tantsitamine - mõrsja esimene esitlemine peiu suguvõsale. Esimese tantsu tantsib noorik peiupoisiga, teise peigmehega. Mõlemad tõstavad tantsu lõppedes nooriku kolm kor- 


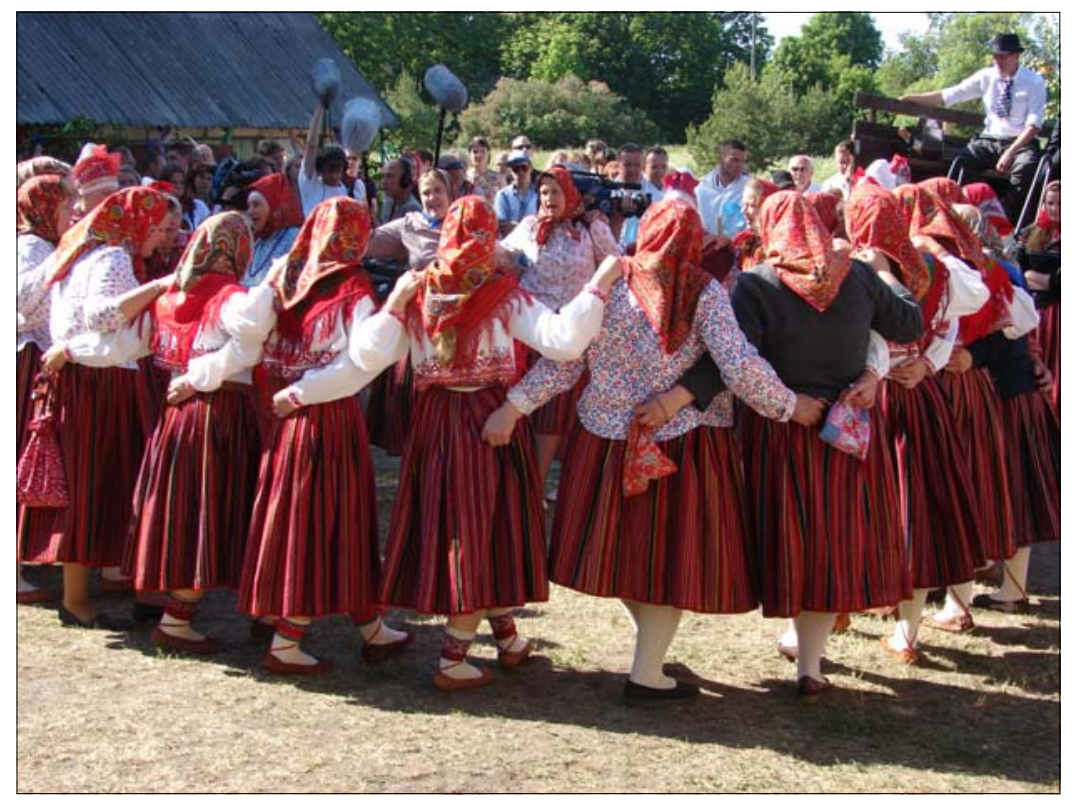

Foto 2. Laulmine rattas peiukodu õuel. Eino Pedaniku foto 2007.

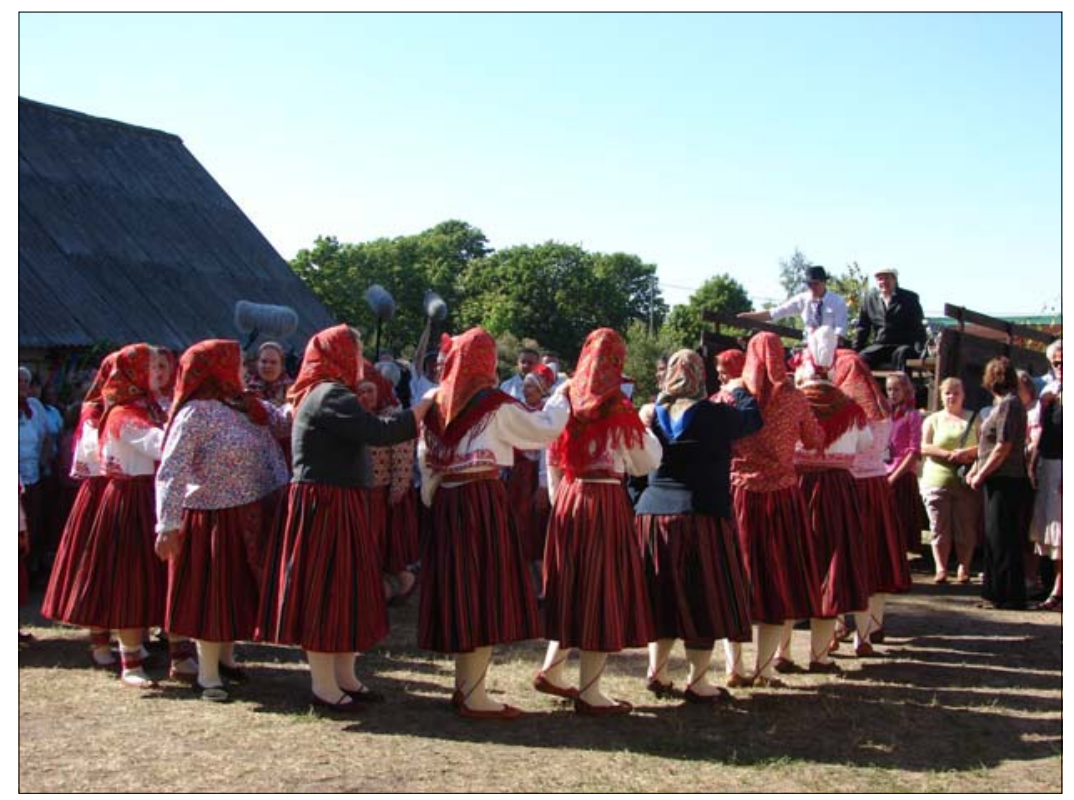

Foto 3. Sama, teine käteasend. Ingrid Rüütli foto 2007. 
da üles, millel vanasti oli ilmselt viljakusmaagiline tähendus nagu muudelgi analoogsetel tõstmistel. Mõlemal puhul hoiab noorik kätt näo ees (nuorik äbe$n e b)$. Seegi võis olla mingi kaitse- või tõrjemaagiline rituaal. Muistsed usukujutelmad on aga ammu ununenud. Kolmandat tantsu alustavad pruuttüdrukud (umbrukad), teised pulmalised tantsivad kaasa. Tänapäeval liituvad umbrukad juba noorpaari tantsuga.*

Kommete vaheajal, eriti teisel ja kolmandal päeval tantsitakse palju lõbustuslikke seltskonnatantse, tänapäeval eriti Kihnu valssi, polkat ja reinlendrit, aga ka kalamiest, neljapuari ja teisi eespool mainitud tantse, kui leidub pillimehi, kes neid mängida oskavad. Kõiki tantsitakse ringis, kusjuures polkat tantsitakse mistahes kiirema, reinlendrit aga aeglasema tempoga 2-osalises taktimõõdus loo järgi.

Kihnu polka ja valss erinevad tavalisest. Polka käib ilma hüppamiseta, hoogsalt keerutades, harilikult valsivõttes. Tüdrukud ja noored naised hoiavad sageli üksteise ümbert kinni, mis võimaldab kiiremini keerutada. Osavamad tantsupaarid keerutavad ühe tuuri päripäeva, teise vastupäeva, samal ajal ikka ringis ühes suunas edasi liikudes. Valsil on kaks tuuri: kõnnituur ja valsituur. Ka valss käib ringjoont mööda. Ilmselt kõnnituuri pärast kutsuti valssi vanasti ka käömälugu. Ka labajalal oli kõnnituur: Kui pää hakkab ringi käima, siis käiakse natuke aega kõrvuti ühekäevõttes kas kõnd-või hüppsammudega (ERA

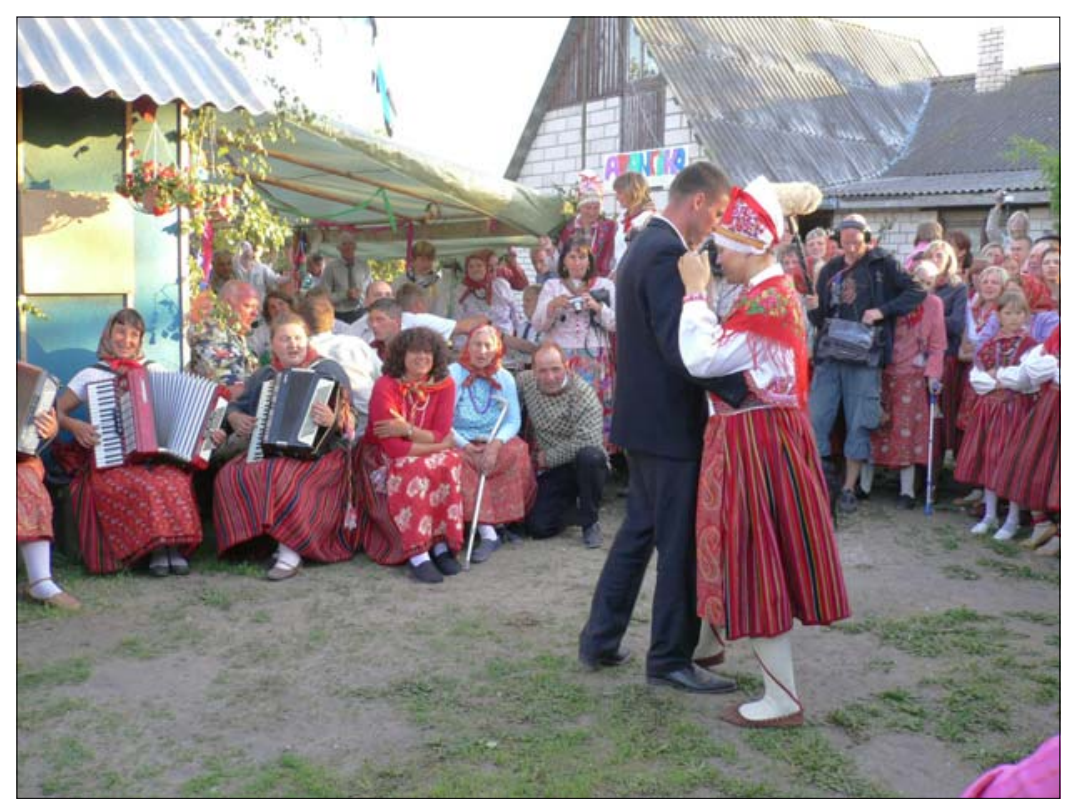

Foto 4. Noorik tantsib peiupoisiga. Ingrid Rü̈ttli foto 2007. 


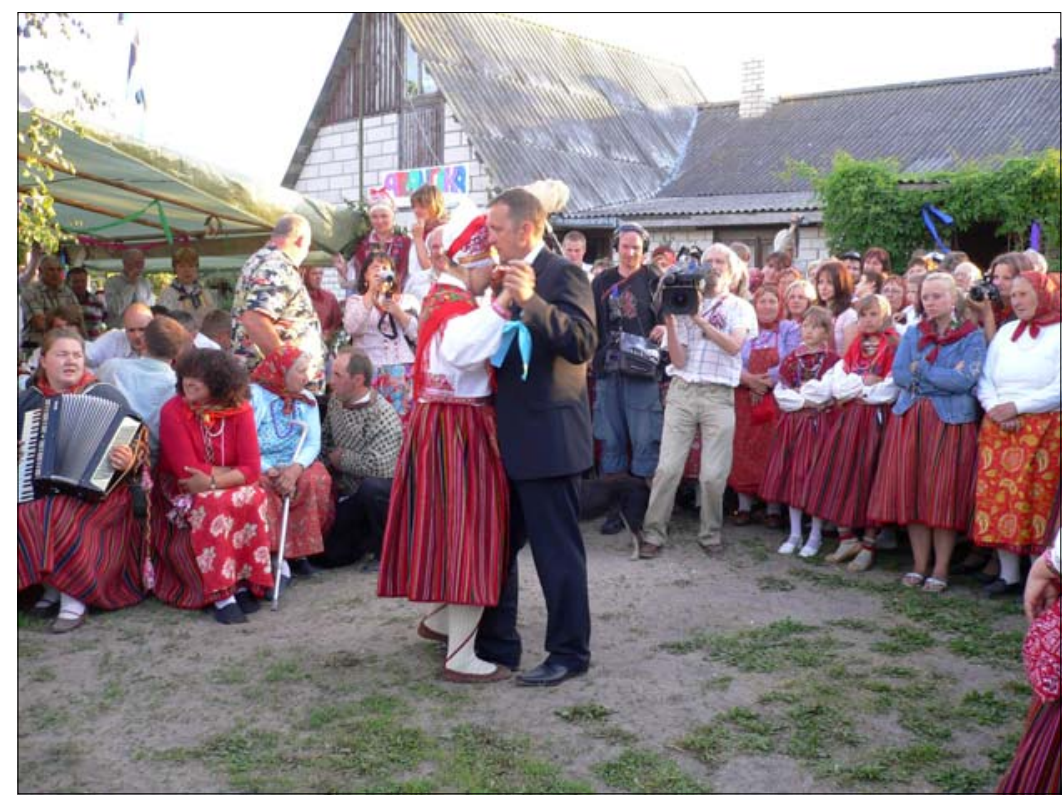

Foto 5. Noorik tantsib peiuga. Ingrid Rü̈̈tli foto 2007.

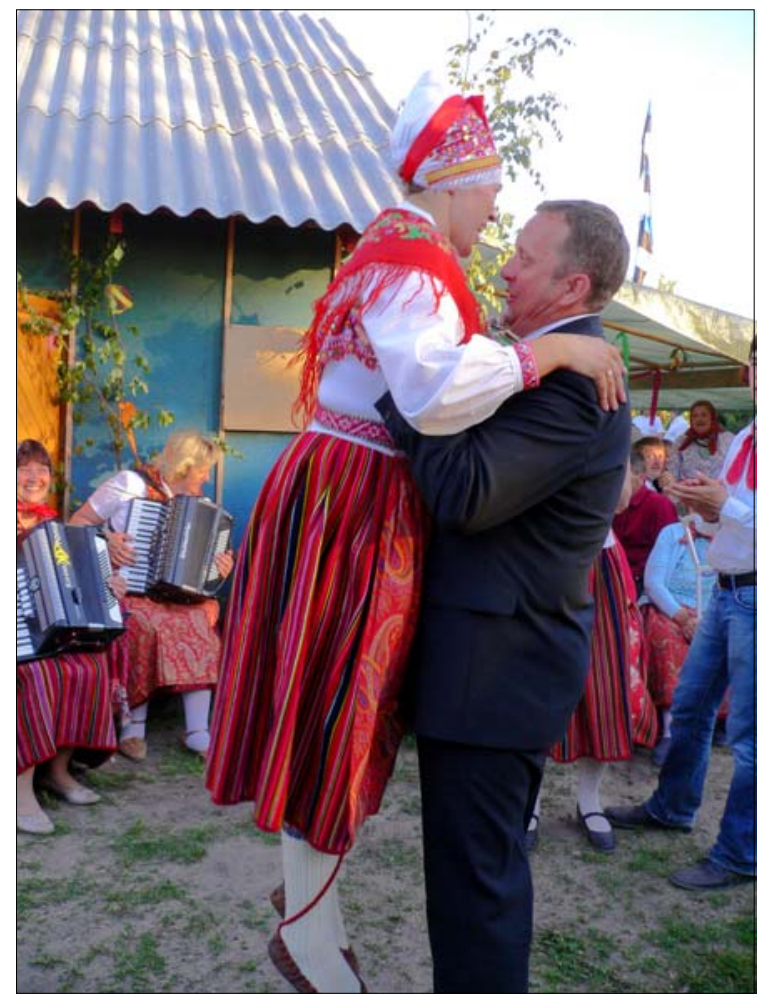

Foto 6. Peigmees tõstab tantsu lõppedes nooriku kolm korda üles. Ingrid Rü̈̈tli foto 2007. 
II 128, 39/40 (6) H. Tampere > T. Saar 1936). Seega tugineb Kihnu valss suurel määral vanade labajalale.

Kadripäeva kombestikus on samuti tantsudel tähtis koht. Vanasti käisid maskeeritud sandid oma küla taludes ande kogumas. Akna taga küsiti: "Kas ond luba laulu lüüa?" Kui sisse lasti, algas tants. Tantsiti valtsõrit, polkat ja russkit (RKM II 27, 670 (12) - A. Strutzkin 1948). Õhtul tulid terve küla noored kokku, söödi, joodi ja tantsiti.

Maskeeritud andidekogujad viimastel aastatel enam tavaliselt talusid mööda ei käi. Filmisime seda Kihnus 25. novembril 1997. Täiesti uus komme oli tantsimine ja pillimäng traditsioonilise regivärsilise kadrilaulu saateks. Talutoas tantsiti polkat. Ent kadrideks ümber kehastunud ei tantsinud tavaliselt, vaid koomilist efekti taotlevalt hoogsamate liigutuste ja kehapainutustega. Tantsu lõppu liitunud külakuhi oli traditsiooniline nali, mida võidi teha muudeski olukordades.*

Õhtul tuldi külade kaupa kokkulepitud taludesse kokku, et pidu pidada ja kogutud toit ühiselt ära süüa. Õlut tehti juba varem valmis. Ka toitu toodi ja tehti lisakski. Pidu kestis tunde. Osalesid kõik soovijad, mitte ainult kadrid mehed, naised, noored ja lapsed. Maskideta tantsiti tavalisi seltskonnatantse oma lõbuks. Kõik tantsud lõppesid pillimeeste tänamise ja hõisetega.*

Öösel riietati kadrideks ka poisid ja mindi teise küla kadrimajja võõrsile. Maskeeritud tantsisid taas tavalisest erinevas stiilis, naljakalt - nad ei olnud nemad ise, vaid ümberkehastunud olendid, kadrisandid.

Peo lõpupoole võeti maskid eest ja kadrirõivad seljast ning tantsiti taas tavaliselt, oma lõbuks, nii nagu seda tehakse mitmesugustel muudelgi pidudel ja koosviimistel.

Viimastel aastatel korraldatakse samuti vahel kadripidusid külades, kuid sagedamini toimub ühine pidu kohalikus restoranis või rahvamajas. Vanad seltskonnatantsud on populaarsed nagu pulmadeski.

Vanasti tehti ringmänge ja tantsiti ka teisel jõulupühal, kui poisid ja mehed käisid mööda talusid, nagu see oli kombeks Muhus ja Saaremaalgi. Külalistele pakuti õlut, pähkleid, vahel ka süüa. Vanal ajal tantsitud siis isegi ratast, mida muidu tantsiti vaid pulmades. Kas sellel võis olla mingi tähendus seoses siirderituaalidega, pole teada.

Eespool tsiteerisime huvitavalt teadet meeste tantsu (russki) esitamisest naiste poolt erilisel naistepühal. Naestõ jaht oli setu baabapraasnikule analoogne naiste omavaheline pidu, kus üldse oli tavaks mehi parodeerida ja millel võis kunagi olla sigivusmaagiline alus. Analoogseid naistepühi olnud erinevail rahvastel. Kihnu naeste jahist on vähe andmeid, kuigi 20. sajandi teisel poolel seda veel kuigivõrd peeti. 


\section{Seltskonnatants pidudel jm koosviibimistel}

Vanasti käidi tantsimas peamiselt neljapäeval ja pühapäeval. Igal külal oli oma traditsiooniline tantsuplats: Linakülas Keiari- ehk Kroonoaid, Säärekülas Kotia'a mulk, Lemsis Ärjäaugu serv, varem Koksi a'a tagunõ, Rootsikülas Sopõrga piälne ja Mardi väräväl, varem Suti a’a tagunõ ( RKM II 56, 653 (4) T. Saar 1959).

Hiljem peeti pidusid peamiselt rahvamajas (hubases puithoones, mis ehitati pärast sõda oma jõududega ühistöö korras), suvel aga rahvamaja kõrval platsil. Kuid koos on käidud ka mujal. Nii oli 1990. aastatel noortel tavaks käia mere ääres lõket tegemas, kartuleid küpsetamas, laulmas ja tantsimas. Eri aegruum, eri situatsioonid tingivad erinevusi tantsustiilides. Lauldi uuemaid lüürilisi laule, ka tants oli vaiksem ja vaoshoium kui näiteks kadripeol või pulmas.*

Üks populaarseimaid pidusid tänapäeval on jaanipäev. Vana tava oli põletada vanu paate. Vahepeal kaduma kippunud komme on viimasel ajal taas hoogu läinud. Jaanipäev on küll traditsiooniline kalendripüha, kuid sellega pole seotud mingeid rituaalseid laule ega tantse. Tantsitakse tavalisi seltskonnatantse. Kuna viimasel ajal käib Kihnus jaanipäeval nagu ka uue rahvamaja pidudel palju turiste, pole tantsimine seal enam päris kihnu moodi. Kihnlased püüavad küll ringis tantsida, turistid aga mitte. Kõikide pidude lahutamatuteks osalisteks on lapsed.*

Viimastel aastatel on jaanipäeval turistide vool saarele nii rohke, et see muutub traditsioonilisele peole ohtlikuks. Võõrad ei tantsi ringis, ka ei riietu nad pidulikult nagu kihnlastel tavaks, mistõttu pidulik rahvariiete kandmine muutub mõttetuks ning kihnlased, eriti vanemad inimesed tunnevad end halvasti ega võtagi pigem peost osa.

Sellel a'al tuleb tuhat võerast Kihnu. Kihnu kogokondõs ond üldse 500 inimest, kis mõistvad sedä kihnu tantsu ning tahtvad oma pidu pidädä. Sie võerastõ suur ulk lämmätab selle, enäm kihnu pidu ei tulõ. Lihtsalt siokõ üks üleüldine läbu.

- Kui ei tuleks turiste nii palju?

Jaa, sie ond üks unistus küll. Teene asi ond, et võib sellele kua käegä leü̈̈, et las ta siis lähäb. Praegu ond küll siokõ olukord, et mõtlõks, et las ta siis jäeb, et lihtsalt ei suuda. Kihnu vanad naesõd kua juba ammu ütleväd, et nad ei taha sjõnna minnä. Kihnlane ehib ... juanipäe naa pühälik pühä, kõik nied saunad ning kaskõ tuõmised ning uiõd asõmariided ning siis nied vällä̃ommõldud pü̈̈rid ning uiõd riided õmmõldassõ, uiõd kördid nind alusriided ning põlvikud, ning kõik naa pühälik, et juanitulõlõ... Ning kui turistid siis ond siäl dressegä ning ükskõik mis muõdi-teesed 
suurõd edevalmistusõd tein, et naa tähtsäd, et lähtväd peole aastas, siis mõtlõd, et mis jaos sie kallist sitsi põll ede panna, et nagu pärlite taotamine sigadõlõ! (Mare Mätase intervjuust).

Siin põrkuvad kokku kaks erinevat sotsiaalset organisatsiooni ja mentaliteeti: suuresti pärimusel põhinev ja traditsioone austav Kihnu kogukond ning postmodernse ühiskonna meelelahutusturistid, kelle eesmärgiks on lihtsalt nende jaoks suhteliselt eksootilises ümbruses lõbusalt aega viita. Ent teisalt põrkub kokku kaks mentaliteeti ka Kihnu kogukonna sees: traditsioonide hoidmine ning turismindusega raha teenimine. Ent nende vahel ei ole selget veelahet ja ehk on edaspidi siiski võimalik leida mingi kompromiss, mis vähendaks jaanipäeval turistide voolu ning suurendaks selliste kultuurituristide osatähtsust, kes austaksid Kihnu kultuuri ja oleksid selle vastuvõtmiseks ka ette valmistatud.

\section{Tantsude õppimine tänapäeval ja tantsimine organiseeritud esinemistel}

Lisaks eespool mainitud juhtudele tantsitakse tänapäeval mitmesugustel organiseeritud üritustel - turistidele mõeldud programmides kodusaarel, samuti festivalidel jm pidudel Kihnus ja väljaspool, sh välismaal. Esinejateks on peamiselt folkloorirühm Kihnumua, kes tegutseb juba üle 40 aasta Katrin Kumpani juhtimisel. Rühma liikmed on pidevalt muutunud ning päris kindlaid koosseise polegi, sest traditsioon on elav. Osa tantsijaid on tantse tundnud varem ja toonud oma oskused rühma kaasa, osa noori on õppinud need rühmas osaledes. Viimastel aastatel seoses folklooriliikumise elavnemisega on ansambli koosseis muutunud eriti vahelduvaks.

Kes on ansambli liikmed? Me ise ka ei tea. Iseenesest on need ju kõik kihnlased, sest ka folkloorifestivalide kavades tutvustame me oma laule, tantse ja käsitööd - elamise / pidutsemise viisi. Kui 1999 oli Kihnumua pidu preemia saamise puhul, olidki sinna kutsutud pea kõik kihnlased, sest eriaegadel on enamus olnud ansambli liikmed, kes kooli ajal või muul põhjusel-rannamängudel esinenud vms. Samuti on folkloorifestivalidega, siis võib tekkida ka tänapäeva meestel / koolipoistel huvi folkloori vastu, muutuvad hetkeks ansambli liikmeks (sest nad kõik oskavad neid tantse ja laule), aga selge on see, et nad turistidele raha eest laulma tantsima ei lähe. Ühesõnaga on ansamblil olemas aktiivne tuumik, kes esineb igal pool ja igal ajal ning teised, kes vahetevahel liituvad (Mare Mätase kiri autorile). 
Kihnu ansamblite esinemised laval või mingil linna üritusel pole siiski kaugeltki sama, mis traditsioonilises keskkonnas. Mitte üksnes koht ja esitussituatsioon ja selleks koostatud kava, vaid ka organiseeritud esinemine ise erineb ometi mõneti tavalisest lõbustuslikust tantsust - tantsustiil on ühtlasem, normeeritum. Mõnel juhul on tehtud ka teadlikke muutusi, lisatud mõnele laulule vahelduseks uusi liikumisi, näiteks vastasmängude elemente. Kuid põhjusi on muidki. Sellega seoses meenub üks ilmekas juhtum.

Kui me 1985. aastal koos Kristjan Toropiga Kihnus välitöödel olles palusime Kihnumua rühmal tantsida kalamiest, alustasid nad tantsu aeglases tempos, keha tahapoole kallutatud jne, sõnaga Kihnule võõras stiilis. Olin väga üllatunud, katkestasin ja küsisin, miks nad nii tantsivad. Nad olid kuidagi ebalevad ega vastanud midagi. Siis hakkas Torop naerma ja meenutas, kuidas nad käisid kunagi Kihnu mängude ajal saarel koos Ullo Toomiga Kihnu tantsurühmale kalameest “õigesti tantsima õpetamas”, kuna need tahtsid pääseda Tallinnasse suurele tantsupeole. Nähes nüüd taas Toropit, arvasid rühmaliikmed paremaks tantsida samal moel. Hiljem läksid nad üle tavalisele stiilile, kuid sealtpeale sugenes komme tantsida kahte esimest tuuri aeglasemalt, kolmandat tuuri aga kiiremas tempos kui esimesi. Vanasti sellist vahet polnud, tantsiti ühtlaselt võrdlemisi kiires tempos.*

Õpetaja Anne Buravkova juhtimisel on kooli juures tegutsenud lasterühm Suarõkõ. Paljud noored on tantsuoskuse omandanud või seda täiustanud, tantsides kooli harrastusrühmas.*

Noortele on tantse õpetanud rahvamaja juhataja, Viljandi Kultuurikolledži kasvandik Veera Leas. Viimasel ajal on Kihnu noored Sihtasutuse Kihnu Kultuuriruum eestvõtmisel käinud tantse õpetamas ka Manijal. Paar aastat on tegutsenud ka Kihnu tantsu klubi, kus on kooliõpilastele tantse õpetanud vanemad naised, kes on mures selle pärast, et Kihnu noored ei tantsi tänapäeval enam päris Kihnu moodi. Kuid tantse on lastele õpetanud ka emad ning vanemad lapsed jm sugulased, samuti on tantsima õpitud lihtsalt pidudel kaasa tantsides, nagu see Kihnus on olnud ajast aega tavaline.*

\section{Lõpetuseks}

Niisiis elavad tänaseni saarel nii vanas kui ka uues kontekstis erinevaist ajastutest pärit tantsud - alates suletud ringis liikumisest vanade regivärsiliste pulmalaulude saatel kuni 20. sajandi alguse seltskonnatantsudeni. Mistahes uute lugude saatel tantsitakse ringis Kihnu valssi, polkat või reinlendrit. Rituaalsetest tantsudest püsib käibel pruudi tantsitamine, tantsitakse ka kadripidudel ja jaaniõhtul. Ühelgi juhul pole aga spetsiaalseid tantse. Pulmaratast 


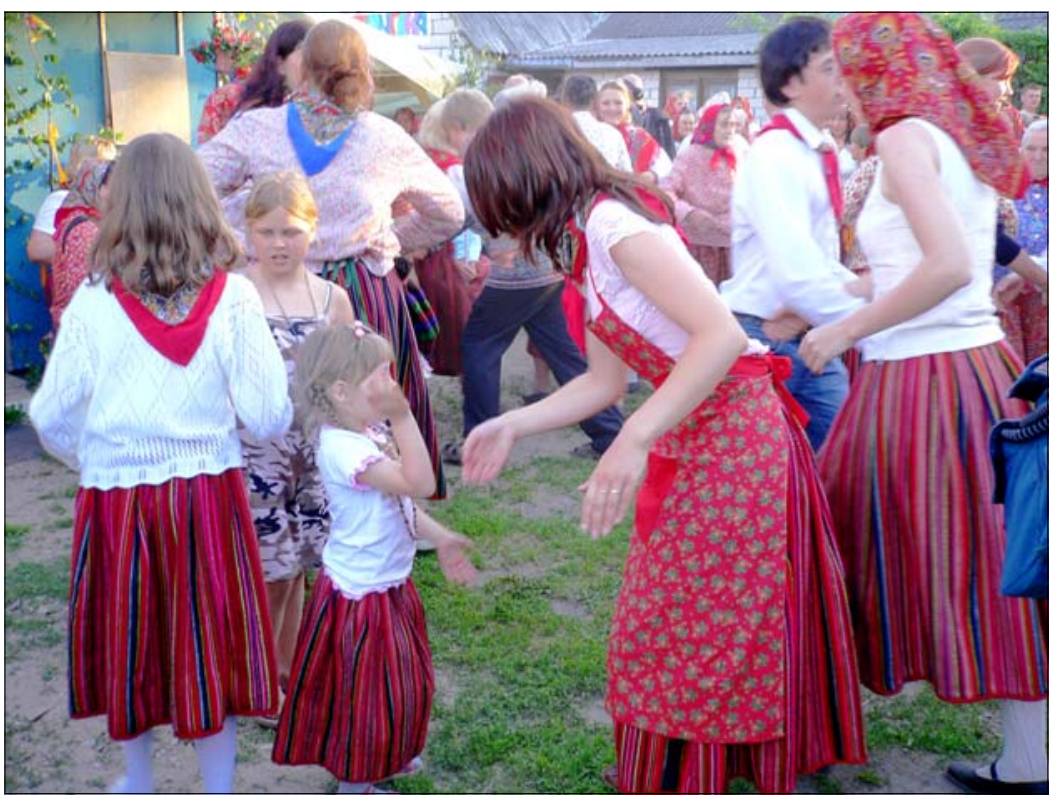

Foto 7. Tants pulmas. Kalamies. Ingrid Rü̈tli foto 2007.

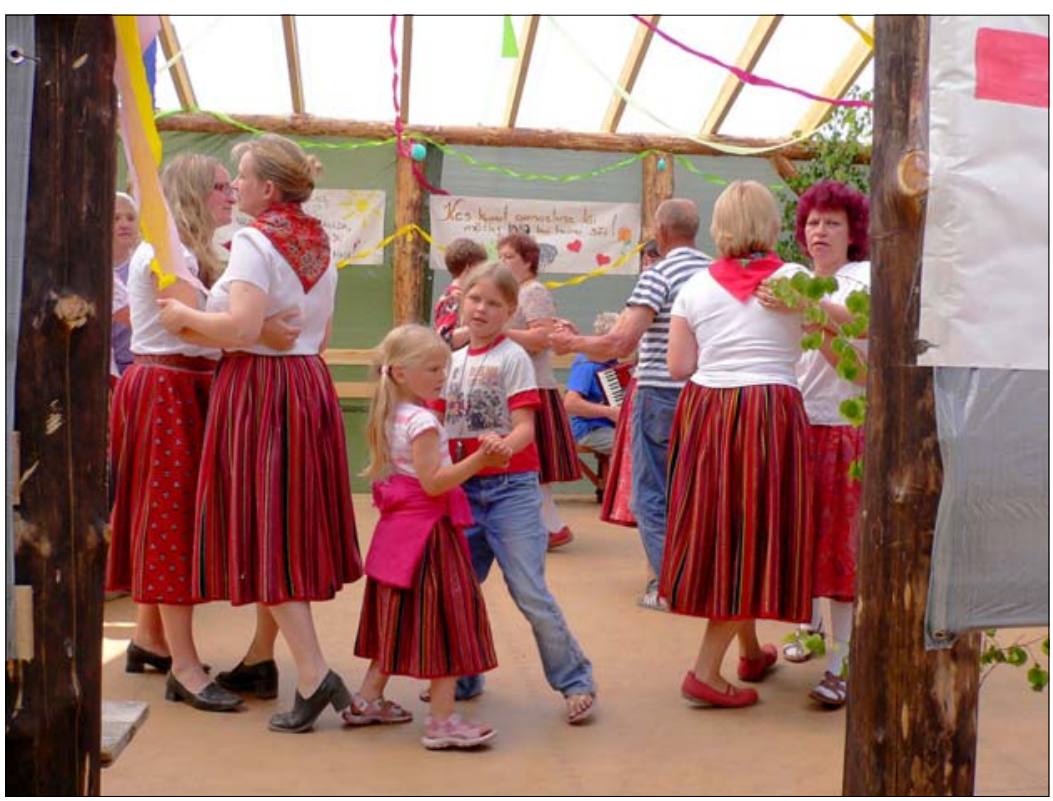

Foto 8. Tants pulmas. Kihnu valss. Ingrid Rü̈̈tli foto 2007. 
enam ei tantsita, küll aga lauldakse pulmalaule ringis liikudes. Pruuti tantsitatakse tavaliselt valsi saatel, pulmades ja kadripidudel tantsitakse kõiki Kihnus tänaseni tuntud tantse. Kuigi naiste omavaheline tants on populaarne, tantsitakse ka segapaaridena. Tähelepanuväärne on laste, eriti tüdrukute tantsuoskus ja -lembus. Nad löövad kaasa kõikjal. Lapsed ja noored armastavad ka improviseerida ja tuua traditsioonilistesse tantsudesse uusi elemente. Jaaniõhtul ja rahvamaja pidudel võtavad viimasel ajal võimust turistid, kes tekitavad segadust, kuna ei tantsi ringis ja eiravad kohalikke tavasid ka riietusega.

20. sajandi teisel poolel on tekkinud uus nähtus - taidlus ning organiseeritud esinemised tänapäeva pidustustel saarel ja väljaspool seda, millele viimasel ajal on lisandunud esinemiskavad turistidele. Vorm ja kontekst on muutunud. Ometi pole see tavaline folklorism, mille olulisemateks erinevuseks ehedast folkloorist peetakse kirjalikku jäädvustamist ja edasiandmist sekundaarsete edasikandjate kihi, organiseeritud gruppide kaudu (Baumann 1976: 6170).

Ehe pärimus ja selle teadlik omandamine, tantsimine ehedas situatsioonis ning organiseeritud üritustel tänapäeva publikule kodusaarel või väljaspool seda on Kihnus omavahel tihedalt põimunud, nagu pole ka kindlaid piire taidlusrühmade liikmete ja ehedate pärimusekandjate vahel. Folkloorirühma liikmete eneste hinnangu kohaselt seob pärimuse teadlik hoidmine ja osalemine folklooriharrastuses kogukonda ühtseks tervikuks, annab elule jõudu ja tuge ning võimaldab anda oma kogemusi edasi lastele (Rüütel \& Tiit 2006, 233).

Kuigi areng sarnastab eluviisid, on eri rahvastel igal juhul oma identiteedi pärand, [---] on ühised sümbolid ja koodid, mida teatud kollektiivi liikmed peavad endale kuuluvaks ja millel on nende jaoks ühine eriline tähendus (Sarmela 1996: 21).

Kihnu tantsutraditsioon on nende sõnade otseseks kinnituseks. See on kihnlaste, eriti Kihnu naiste jaoks kestvaks identiteedi märgiks, nagu ka laulud, rahvarõivad ja kollektiivsed tavad. Need on hoidnud ja tugevdanud kogukonnatunnetust, mis on Kihnu kultuuri kandnud minevikust tänaseni ja ühtlasi aidanud kindlustada selliseid kihnlastele tähtsaid meeleseisundeid, nagu sisemine tasakaal, südamerahu ja rõõmus meel (Rüütel \& Tiit 2006: 218).

Sealjuures on tähelepanuväärne kihnlaste oskus võtta vastu uuendusi, ühendada need varasema pärimusega ning sulatada oma kogukonna ainuomasesse kultuuritervikusse. Siinjuures on mehed olnud peamised uuenduste toojad, naised peamised sotsiaalse valiku tegijad, traditsiooni kujundajad ja hoidjad. 


\section{Kommentaarid}

* Videonäited on kättesaadavad ajakirja elektroonilises versioonis aadressil http:// www.folklore.ee/tagused/nr41/kihnunaide.pdf

1 Kihnu kirderannas paiknes kuni 17. sajandini katoliku kabel, mille asupaiga nimetus on tänaseni Vanakiriku. 1642. aastal ehitati saarele Tõstamaa abikirik, seega võis tantsimine tekkida hiljemalt 17. sajandi teisel poolel, kui veel püsisid kabeli müürid. Surnuaeda ümbritseval kiviaial olevat aga tantsitud veel 1940. aastatel (Rosalie Karjami kiri autorile).

${ }^{2}$ Tantsude nimed on siin ja edaspidi säilitatud kogujate kirjapandud kujul.

\section{Arhiiviallikad}

ERA = Eesti Rahvaluule Arhiivi rahvaluulekogu, 1927-1944.

RKM = Riikliku Kirjandusmuuseumi (nüüd Eesti Kirjandusmuuseumi) rahvaluule kogu, 1945-1996.

TRÜ EKRK = Tartu Riikliku Ülikooli eesti keele kateedri rahvaluulekogu.

\section{Kirjandus}

Baumann, Max Peter 1976. Musikfolklore und Musikfolklorismus. Eine Ethnomusikologische Untersuchung zum Funktionswandel des Jodels. Amadeus Verlag.

Hoppu, Petri 1999. Kansantanssin tutkimus ja teoria. Rahvatantsu uurimine: arhiivid, meetodid, teooriad. Kansantanssin tutkimus: arkistot, menetelmät, teoriat. Sümpoosioni materjalid. Viljandi Kultuurikolledž, lk 18-19.

Delgado, Ángel Acuña 2005. Dance as an Analytic Model for Social and Cultural Interpretation: a Case Study. Dunin, Elsie Ivancich \& Bibra Wharton, Anne \& Felföldi, László (toim). Dance and Society. Dancer as a Cultural Performer. Re-appraising Our Past, Moving into the Future. 40th Anniversary of Study Group on Ethnochoreology of International Council on Traditional Music. Budapest: Akadémiai Kiadó \& European Folklore Institute (http://www.sulinet.hu/oroksegtar/data/Idegen_nyelvu_kiadvanyok/ Dance_and_society/pages/003_re_appraising.htm - 1. aprill 2009).

Kõiva, Ottilie 1987. Eesti pulmalaulude esitamistavadest. Sarv, Ingrid (koost). Rahvaluulest. Emakeele Seltsi toimetised 21. Tallinn: Eesti NSV Teaduste Akadeemia, lk 126-141.

Niidu [Kumpan] Katrin 2008. Kihnu nuõrdõ lauluvihk. Kihnu: Kihnu Kultuuriruum.

Rüütel, Ingrid 1995. Kihnu pulmakombed - juured ja suundumused. Hiiemäe, Mall \& Kõiva, Mare (toim). Rahvausund tänapäeval. Tartu: Eesti TA Eesti Keele Instituut, lk 328-353. 
Rüütel, Ingrid \& Tiit, Ene Margit 2006. Pärimuskultuur Eestis: kellele ja milleks II. Eesti Kirjandusmuuseumi etnomusikoloogia osakond. Tartu: Tartu Ülikooli Kirjastus.

Saarikoski, Helena 2003. Ruumiintekniikosta tanssien antropologiaan. Saarikoski, Helena (toim). Tanssi, tanssi. Kulttuureja, tulkintoja. Tietolipas 186. Helsinki: Suomalaisen Kirjallisuuden Seura.

Sarmela, Matti 1996. Suomalainen eurooppalainen. Laaksonen, Pekka \& Mettomäki, Liisa (toim) Olkaamme siis suomalaisia. Kalevalaseuran vuosikirja 75-76. Helsinki: SKS, lk 16-34.

\section{Summary}

\section{Traditional Dances of the Kihnu Island, Estonia}

\section{Ingrid Rüütel}

Key words: folk dance, folk group Kihnumua, Kihnu, partner dance, round dance, wedding circle dance ("wheel dance")

Kihnu is a small island off the western coast of Estonia, where a number of traditional cultural phenomena have been preserved. Quite a number of traditional dances are kept alive in the traditional and modern context. These dances are danced at traditional family and calendar events: pre-wedding rituals and weddings, gatherings on the eve of St Catherine's Day, as social dances at different festivities, during organized performances for tourists, and at festivals and other events on the Kihnu island as well as in Estonian towns and abroad. The dancers are mainly members of the amateur group Kihnumua, which has been active for more than 30 years under the guidance of Katrin Kumpan. The groups have no fixed membership, as most of the island's inhabitants know the tradition. Dances were taught also in the local school and dance club. Some old round and partner dances have disappeared, but about 10-15 dances, mostly partner dances, are still in active use. All partner dances (incl. waltz and polka) are danced in a circle. Couples can be mixed, though women often dance among themselves. Many widely known dances have specific regional style variants. The main musical instrument nowadays is accordion, which is often played by women. Bagpipe music is forgotten, and good fiddlers were found up to the mid-20th century. Also, hand harmonica, the most popular musical instrument of the late 19th and early 20 th century, has become rather rare by now. 